\title{
Pengaruh Pakan Buatan Kedelai (Glycine max L) dan Kacang Merah (Phaseolus vulgaris L.) Terhadap Pertumbuhan Larva dan Produksi Kokon Ulat Sutera (Bombyx mori L)
}

\author{
Rosdiana $^{1 *}$ \\ ${ }^{1}$ Balai Diklat Lingkungan Hidup dan Kehutanan Makassar \\ *Email: rosdianabdk2@gmail.com
}

\begin{abstract}
Sericulture or silk farming is one of forest product non wood which product cocoon and then spun become raw silk. National demand of cocoon is high equivalent 900 ton/year. National cocoon production only $5 \%$, and $95 \%$ import from Cina. The quality of mulberry leaf is bad and limited in dry season. One way to replace mulberry's leaf as natural food is provide artificial feed. The aim of this research is to know the influence in giving artificial feed to larvae and cocoon production as well as to know the best various artificial feed is made from soybean and kidney bean. This research was conducted in silk center of environment and forestry education and training center Makassar from April until July 2019. This research uses Complete Random Design and Data analyzed by using Analysis of Variance (ANOVA). The best variation of artificial feed for growth larvae are kidney bean (Phaseolus vulgaris L.) and soybean (Glycine max $L)$, the results showed that average of weight larvae and increase of weight larvae, growth index, the average of length larvae are more than larvae indicator, although the Tukey Test stated that it is not significantly different from the indicator. Then for cocoon production, kidney beans heaviest for fresh cocoon, heavy fiber, percentage of cocoon skin and length of fiber nearly same indicator. While soybean, is the best in strength of fiber, however it is shortest of its fiber, weight of larvae is lightest, growth index and percentage of skin cocoon are the lowest.
\end{abstract}

Keywords: Artificial feed, growth of larvae, cocoon production DOl: http://dx.doi.org/10.24259/jhm.v11i2.8298

\section{PENDAHULUAN}

Sutera alam menjadi salah satu komoditi unggulan bagi Indonesia khususnya di Sulawesi Selatan karena iklim dan kondisi alamnya sangat mendukung sesuai kebutuhan ulat sutera yakni tumbuh optimal pada ketinggian kurang lebih $700 \mathrm{~m}$ dpl, dengan suhu $25^{\circ} \mathrm{C}-28^{\circ} \mathrm{C}$ (Atmosudarjo et.al,2000). Peran persuteraan alam cukup strategis karena: 1) dapat melibatkan petani dan keluarganya sebagai tenaga kerja, 2) membuka kesempatan usaha, 3) memberi kesempatan mengembangkan ekonomi kerakyatan, 4) meningkatkan pendapatan petani, 5) meningkatkan devisa, 6) dan membuka peluang bisnis di bidang jasa.

Budidaya Ulat Sutera merupakan salah satu usaha Hasil Hutan Bukan Kayu (HHBK) yang menghasilkan kokon. Dari bahan baku kokon kemudian dipintal menjadi benang sutera mentah atau raw silk. Benang Sutera mentah selanjutnya diolah menjadi benang siap pakai sebagai bahan baku 
kain sutera. Bahan baku kain sutera ini sangat dibutuhkan masyarakat Sulawesi Selatan yang menggantungkan usahanya pada usaha persuteraan.

Pakaian adat Bugis Makassar yakni Baju Tokko/ Baju Bodo pakaian adat perempuan dan sarung sutera disebut Lipa' Sabbe berbahan dasar kain sutera. Pada berbagai acara pakaian ini semakin sering dipakai oleh berbagai kalangan. Karena itulah pemerintah dalam hal ini Gubernur Sulawesi Selatan menghimbau masyarakat agar tetap melakukan pemeliharaan Ulat Sutera pada daerah-daerah penghasil sutera untuk mengembalikan kejayaan sutera di Sulawesi Selatan, hal ini diungkapkan Gubernur Sulawesi Selatan pada puncak perayaan HUT ke 620 Kabupaten Wajo (Sulselprov.go.id, 2019).

Kebutuhan kokon setahun mencapai 7.200 ton dan benang sutera pertahunnya 900 ton. Indonesia saat ini hanya bisa memenuhi $5 \%$ dari kebutuhan tersebut, sedangkan $95 \%$ lainnya diimpor dari Cina. Padahal kualitas produk sutera alam di Indonesia lebih tinggi dibandingkan dengan produk Cina (FORDA, 2016). Sejalan hal ini, Atmosoedarjo, et al. (2000), menyatakan kebutuhan benang sutera di Indonesia kurang lebih 600 ton/tahun, sementara produksi dalam negeri baru mencapai kurang lebih 85 ton/tahun. Hal ini menunjukkan peluang untuk pengusahaan benang ulat sutera sangat tinggi.

Ulat sutera (Bombyx mori L) mampu menghasilkan serat benang sutera. Serat benang sutera ini dihasilkan pada akhir fase larva instar lima biasa juga disebut ulat besar. Ulat besar banyak membutuhkan pakan, menurut Atmosoedarjo,et al. (2000), kebutuhan pada saat ulat besar banyak membutuhkan pakan yaitu daun murbei bersama ranting kurang lebih 1,8 ton per boks ulat. Pada ulat instar 5 membutuhkan pakan $90 \%$ dari total kebutuhan pakan selama fase ulatnya. Jika pakan tidak memadai dapat mempengaruhi kondisi ulat dan produktivitas kokon. Sejalan dengan hasil penelitian Nurhaedah, et al. (2006) yang menyatakan bahwa produktivitas kokon ulat sutera banyak dipengaruhi dari jenis-jenis murbei pakan ulat sutera.

Selama ini ulat sutera hanya memakan daun murbei sebagai pakan pokok, akan tetapi produksi daun murbei tersebut berfluktuasi disebabkan karena musim dan luas lahan kebun murbei semakin berkurang. Salah satu cara untuk mengatasi kekurangan pakan adalah dengan memberikan pakan tambahan dari bahan olahan daun murbei dengan bahan lainnya yang disebut pakan tambahan buatan. Pakan buatan merupakan pakan olahan dari bahan daun murbei dengan bahan lainnya. Daun murbei masih tetap dicampurkan untuk menarik minat ulat memakan pakan buatan. 
Chowdhary (1996) menyatakan, pemeliharaan ulat sutera jika hanya mengandalkan pakan alami saja memerlukan lahan yang sangat luas. Pakan buatan ini sangat penting bagi ulat sutera sebagai pakan tambahan yang berkualitas yang diharapkan dapat mengatasi kekurangan pakan murbei sebagai pakan alternatif, yang dapat melanjutkan kehidupan ulat, dan meningkatkan kualitas ulat serta, produktivitas kokon dan benang sutera. Pemberian pakan tambahan buatan dapat mempengaruhi berat larva, yakni larva yang diberikan pakan tambahan lebih berat dibanding dengan larva yang hanya diberikan pakan murbei, demikian juga panjang larva lebih panjang yang diberikan pakan buatan. Selain itu juga mempengaruhi berat kokon, lebih berat yang diberikan pakan buatan yang berbahan kacang merah(Lestari C.A., 2019).

Pemberian pakan tambahan buatan terhadap Ulat Sutera oleh masyarakat, diharapkan pemeliharaan dapat dilakukan setiap saat, tidak lagi dibatasi dengan musim dan jumlah daun murbei sehingga pemeliharaan secara terus-menerus yang dapat meningkatkan pendapatan dan kesejahteraan petani.

\section{METODE PENELITIAN}

\subsection{Waktu dan Tempat}

Penelitian ini dilaksanakan pada bulan April 2019 sampai dengan bulan Mei Tahun 2019 di Rumah Sutera BDLHK Makassar dan Pengukuran Serat kokon dilakukan pada Balai Perhutanan Sosial dan Kemitraan Lingkungan di Kabupaten Gowa Sulawes Selatan

\subsection{Teknik Pengumpulan Data}

a. Bahan dalam penelitian ini adalah ulat sutera (Bombyx mori $L$ ) Instar $V$ sebanyak 50 ekor/perlakuan dengan 4 kali ulangan 3 variabel dan 1 kontrol, membutuhkan ulat 800 ekor. Bibit ulat sutera ini berasal dari Perum Perhutani Kab. Soppeng Provinsi Sulawesi Selatan, kaporit, kapur, larutan formalin, daun murbei, kacang merah, kacang kedelai, agar-agar, vitamin C, dekstrosa dan air

b. Formulasi pakan buatan : komponen pembentuk pakan buatan sesuai dengan perlakuannya adalah P1 (Campuran 44 \% Murbei segar, 32 \% Tepung Kacang Merah, P2 (Campuran dari: $44 \%$ Murbei, $16 \%$ Tepung Kacang Merah, 16 \% Tepung Kedelai), P3 (Campuran dari: $44 \%$ Murbei, 32 \% Tepung Kacang Kedelai), P4 (Pakan alami daun murbei segar sebagai control). 
Perlakuan P1, P2 dan P3 masing-masing ditambahkan $15 \%$ Agar-agar, 8 \% Gula pasir dan 1 $\%$ Vitamin C dan air $500 \mathrm{ml}$.

\subsection{Analisis Data}

Penelitian ini menggunakan Rancangan Acak Lengkap dengan 3 perlakuan kombinasi pakan dan masing-masing perlakuan terdiri dari 4 ulangan ditambah kontrol. Parameter yang diamati pada penelitian ini adalah produktivitas larva (berat dan panjang larva, indeks pertumbuhan) dan produktivitas kokon (berat kokon, berat kulit kokon, persentase kulit kokon, panjang serat, dan berat serat, serta kekuatan serat). Data dianalisis dengan analisis sidik ragam (Analysis of Variance, ANOVA). Apabila perlakuan memberikan pengaruh yang nyata, maka dilanjutkan dengan uji Tukey. Parameter yang menggunakan rumus perhitungan adalah:

a. Indeks Pertumbuhan (\%)

$=$ Berat akhir larva $(\mathrm{g})$ - Berat awal larva $(\mathrm{g}) \times 100 \%$

Berat akhir larva (g)

b. Persentase berat kulit kokon (\%)

$=$ bobot kulit kokon $\times 100 \%$

Bobot kokon segar

\section{HASIL DAN PEMBAHASAN}

\subsection{Pengaruh Pemberian Pakan Tambahan buatan terhadap Larva Instar V Ulat Sutera (Bombyx mori. L).}

Selama ini daun murbei merupakan pakan tunggal dengan tingkat palatabilitas tinggi bagi Bombyx mori L. Pada daun murbei terdapat suatu zat perangsang yaitu glukosida. Hal ini yang menyebabkan penolakan memakan daun tumbuhan lain karena tidak adanya zat perangsang tersebut (Sunanto, 1997). Murbei menjadi pakan khusus untuk pemeliharaan ulat sutera karena adanya kandungan senyawa morin dan $\beta$-sitosterol yang menjadi senyawa atraktan (penarik) bagi ulat sutera (Ramesh et al.,2014). Sehubungan dengan hal di atas, maka pembuatan pakan tambahan buatan berbahan kacang merah (Phaseolus vulgaris L.) dan kacang kedelei (Glycine max L. Merr) diberikan tepung murbei yang dapat menarik penciuman ulat sutera. 
Pakan buatan berbahan campuran kacang merah dapat dikonsumsi oleh ulat sutera dengan kemampuan makan tertinggi 558,11 g campuran daun murbei dan tepung kacang merah $44 \%: 32$ $\%$ pada instar $\mathrm{V}$ dan berpengaruh terhadap indeks pertumbuhan ulat, panjang larva, dan berat larva (Lestari C.A., 2019).

\subsubsection{Pengaruh Pemberian Pakan Tambahan Buatan Terhadap Berat Larva}

Pemberian pakan tambahan buatan dapat mempengaruhi berat larva (Lestari C.A., 2019). Larva yang paling berat adalah yang diberikan perlakuan P1 (berbahan $44 \%$ Murbei, $32 \%$ Kacang Merah, $15 \%$ Agar-agar, 8\% Gula pasir dan 1\% Vitamin C), yang berat larva rata-rata per ekor 2,69 gram, hal ini melebihi berat kontrol (2,68 gram). Disusul dengan perlakuan P2 (berbahan $44 \%$ Murbei, $16 \%$ Kacang Merah, $16 \%$ Kacang Kedelei, $15 \%$ Agar-agar, 8\% Gula pasir dan 1\% Vitamin C) dengan berat larva rata-rata 2,09 gram, dan yang paling rendah adalah perlakuan P3 (berbahan $44 \%$ Murbei, $32 \%$ Kacang Kedelei, $15 \%$ Agar-agar, 8\% Gula pasir dan 1\% Vitamin C) dengan berat rata-rata 2,00 gram. Hal ini dapat dilihat pada Gambar 1, hasil Uji Tukey pada Tabel 1. Juga dapat dilihat bahwa antara P1 dan P4 berat Larvanya berbeda tidak nyata. Sementara P1 berbeda nyata dengan P2 dan P3. Demikian juga pertambahan bobot rata-rata per ekor yang paling tinggi adalah pemberian pakan tambahan buatan P1 yaitu 1,92 gram menyamai kontrol dan yang paling rendah adalah P3 yang berbahan campuran kedelai yaitu 1,24 gram. Untuk lebih jelasnya dapat dilihat pada Gambar 1.

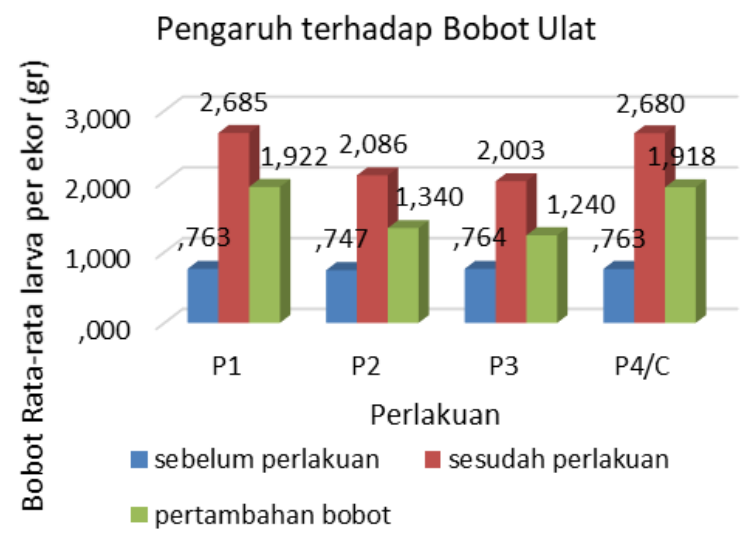

Gambar 1. Pengaruh pakan tambahan terhadap Bobot Ulat Sutera 
Indeks pertumbuhan dapat dihitung dengan rumus berat Larva setelah perlakuan dikurangi berat larva, sebelum perlakuan, dibagi dengan berat larva setelah perlakuan dikali dengan $100 \%$. Hasil menunjukkan bahwa yang paling tinggi Indeks pertumbuhannya adalah P1, pakan yang berbahan campuran kacang merah lebih tinggi pertumbuhannya dari pertumbuhan kontrol, dan yang paling rendah adalah P3 campuran yang berbahan kedelai. Hal ini dapat dilihat pada Gambar 2 dan Tabel 1. di bawah ini:

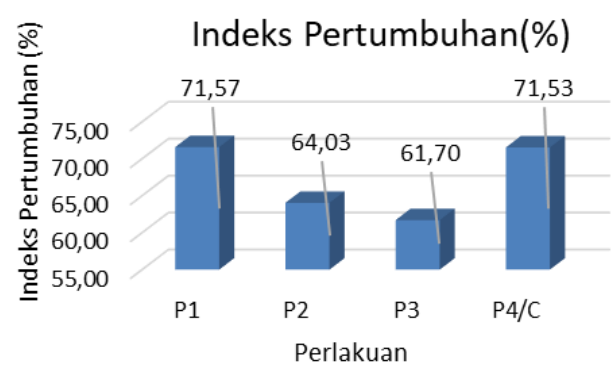

Gambar 2. Indeks pertumbuhan Larva untuk setiap perlakuan

\subsubsection{Pengaruh Terhadap Panjang Larva}

Panjang Larva dapat dipengaruhi dari pakan tambahan buatan yang diberikan (Lestari C.A., 2019). Data hasil penelitian ini menunjukkan bahwa ulat yang diberikan pakan tambahan buatan pada awalnya tidak berbeda nyata yaitu panjangnya berkisar 4,00 - 4,03 cm, awal instar lima. Setelah diberikan perlakuan, hasil menunjukkan bahwa terjadi perbedaan yang nyata. Pertambahan panjang larva rata-rata paling tinggi adalah P1 yakni $7,31 \mathrm{~cm}$, dan panjang rata-rata kontrol adalah $7,29 \mathrm{~cm}$. Pertambahan panjang larva yang paling rendah adalah pada perlakuan P3 campuran berbahan kedelai, untuk melihat lebih jelas dapat dilihat pada Gambar 3 di bawah ini:

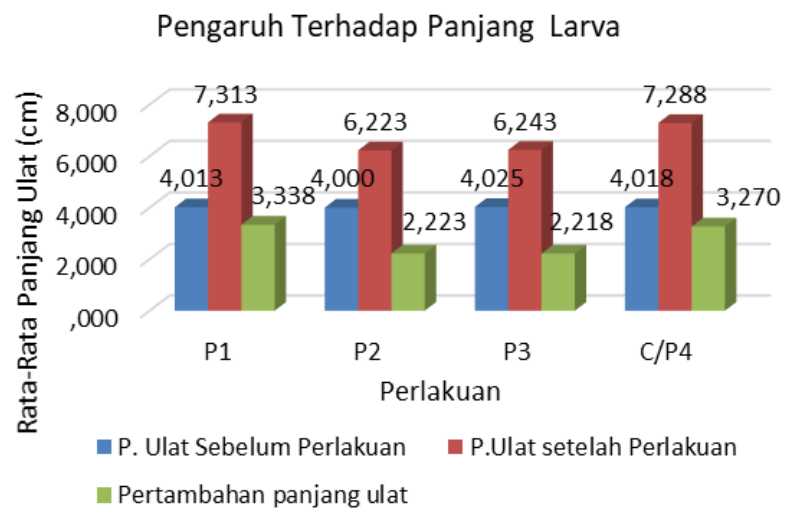




\section{Gambar 3. Pengaruh Terhadap Panjang Larva Ulat Sutera}

Dari hasil pemberian pakan, produktivitas larva (pertambahan panjang larva, pertambahan berat larva dan indeks pertumbuhan dilanjutkan dengan Uji Tukey yang hasilnya dapat dilihat pada Tabel 1 berikut ini:

Tabel 1. Produktivitas larva dengan pemberian pakan tambahan

\begin{tabular}{|c|c|c|c|}
\hline Perlakuan & $\begin{array}{c}\text { Pertambahan Panjang } \\
\text { Larva }(\mathrm{cm})\end{array}$ & $\begin{array}{c}\text { Pertambahan } \\
\text { Berat Larva }(\mathrm{g})\end{array}$ & $\begin{array}{c}\text { Indeks Pertumbuhan } \\
(\%)\end{array}$ \\
\hline P1 & $3,30 \mathrm{a}$ & $1,92 \mathrm{a}$ & $71,57 \mathrm{a}$ \\
\hline P2 & 2,22 b & $1,34 \mathrm{~b}$ & $64,03 \mathrm{~b}$ \\
\hline P3 & 2,22 b & $1,24 \mathrm{~b}$ & $61,71 \mathrm{~b}$ \\
\hline P4 & $3,27 \mathrm{a}$ & $1,92 \mathrm{a}$ & $71,53 \mathrm{a}$ \\
\hline
\end{tabular}

Keterangan: Angka-angka pada kolom yang sama yang diikuti huruf yang sama tidak berbeda nyata pada taraf nyata $5 \%$ menurut Uji Tukey

Hasil penelitian ini menunjukkan sejalan dengan pernyataan pakan buatan berpengaruh terhadap indeks pertumbuhan ulat, panjang larva, dan berat larva (Lestari C.A., 2019).

\subsection{Pengaruh Pemberian PakanTambahan Buatan terhadap Produksi kokon}

Penggunaan pakan buatan juga mempermudah dalam meningkatkan kualitas Kokon, karena lebih mudah mengatur kandungan nutrisi seperti yang diperlukan ulat dan lebih mudah (lebih homogen) dicampurkan zat-zat perangsang pertumbuhan atau lainnya yang diperkirakan dapat memacu pertumbuhan ulat. Secara alamiah ulat sutera B. mori memakan daun murbei tetapi ulat ini dapat hidup dengan baik dan berkembang biak dengan pakan buatan (Kumaidi dan Ekastuti, 2013). Ulat sutera $B$. mori bahkan dapat hidup dengan baik ketika mengonsumsi pakan buatan, asalkan di dalam pakan tersebut ditambahkan tepung murbei atau zat kimia yang ada di daun murbei. Mutu pakan sangat mempengaruhi pertumbuhan dan produktivitas ulat sutera (Pelicano et al. 2004; Ekastuti 2005). Sesuai pernyataan di atas, sejalan dengan hasil penelitian ini menunjukkan bahwa pemberian pakan tambahan buatan berpengaruh terhadap bobot kokon segar, persentase kulit kokon, panjang serat, berat serat dan kekuatan serat, yang dapat dilihat pada pembahasan berikut. 


\subsubsection{Bobot Kokon Normal Segar dan Persentase Kulit Kokon}

Pakan tambahan buatan dapat menyebabkan perbedaan berat kokon: seperti berat kokon segar, berattebal dan tipisnya kulit kokon, dan berat pupa. Hasil penelitian ini menunjukkan bahwa pada Gambar 4, berat kokon segar yang paling berat adalah kokon yang diberikan perlakuan P1, yakni pakan berbahan campuran kacang merah melebihi berat kokon kontrol, menyusul kokon berasal dari larva yang diberi pakan tambahan berbahan kedelai (P3) dan yang paling rendah beratnya adalah kokon berasal dari larva yang diberi pakan tambahan campuran kedelai dan kacang merah (P2).

Berat Kokon Segar Rata-Rata

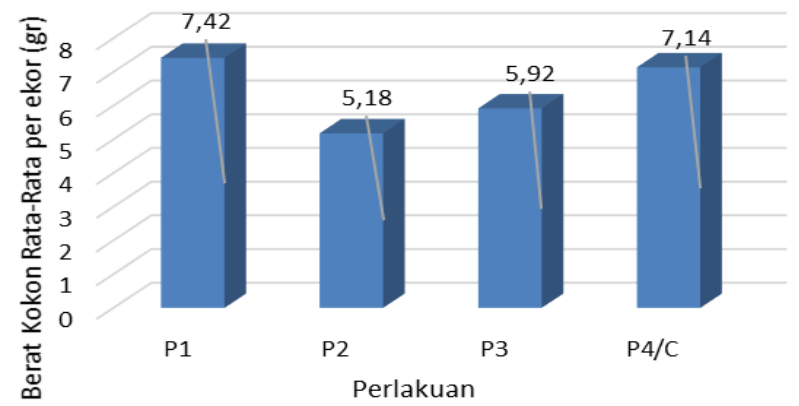

Gambar 4. Berat Kokon Segar Rata-Rata untuk setiap Perlakuan.

Presentasi kulit kokon dapat dihitung dengan berat kulit kokon dibagi dengan berat kokon segar dikalikan dengan $100 \%$. perlakuan yang hasilnya hampir menyamai kontrol adalah P1 (pakan yang berbahan campuran dengan kacang merah) yakni 29,68\%. Berikutnya adalah P2 (Pakan yang berbahan campuran dengan kacang merah dengan kedelai) yang bernilai 28,62\%, dan yang paling rendah adalah perlakuan P3 (pakan yang berbahan campuran kacang kedelei) yaitu 17,42\%. Ratarata Persentase Kulit Kokon dapat dilihat pada Gambar 5 dan Uji Tukey pada Tabel 2 di bawah ini.

Rata-Rata Persentase Kulit Kokon (\%)

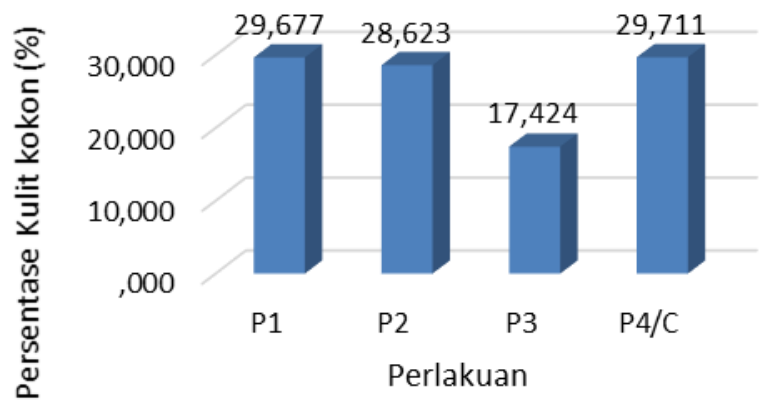


Gambar 5. Rata-Rata Persentase kulit kokon (\%).

\subsubsection{Panjang dan Kekuatan Serat}

Panjang serat yang dihasilkan berbeda-beda dari perlakuan yang diberikan. Serat kokon yang paling panjang adalah serat kokon dari P1 (berbahan $44 \%$ Murbei, $32 \%$ Kacang Merah, $15 \%$ Agar-agar, 8\% Gula pasir dan 1\% Vitamin C) hampir sama dengan panjang serat kontrol, yaitu 685 m, dengan satu kali putus. Kemudian perlakuan P3 (berbahan 44 \% Murbei, 32 \% Kacang Kedelei, $15 \%$ Agar-agar, 8\% Gula pasir dan 1\% Vitamin C) panjang serat yaitu 523,8 m dengan dua kali putus, dan yang paling pendek seratnya adalah P2 (berbahan $44 \%$ Murbei, $16 \%$ Kacang Merah, 16 $\%$ Kacang Kedelei, $15 \%$ Agar-agar, 8\% Gula pasir dan 1\% Vitamin C) panjang serat yaitu 490,4 meter ddengan 1 kali putus. Data selengkapnya dapat dilihat pada Gambar 6 dan Tabel 2 di bawah ini:

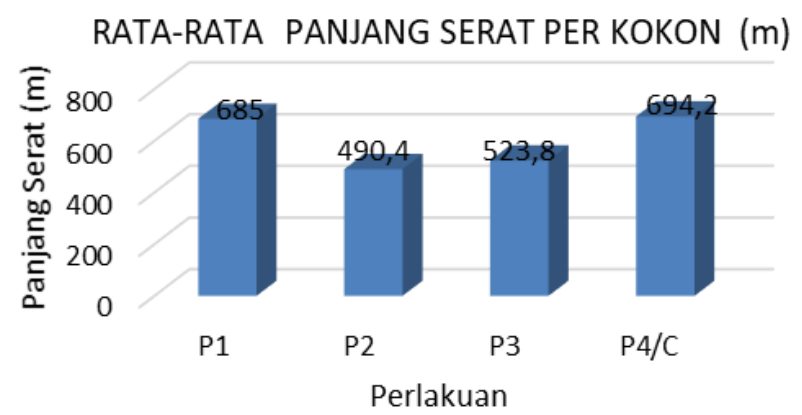

Gambar 6 Perbandingan Panjang serat dari berbagai perlakuan

Dari data banyaknya serat putus, yang paling banyak putus adalah kokon P2 yakni bahan yang bercampur antara kacang kedelei dan kacang merah yaitu tiga kali putus, dan yang paling sedikit putus adalah serat yang berasal dari kedele yakni hanya 1 kali. Untuk kontrol dan P2, yang berbahan Kacang merah putus sebanyak dua kali. Sehingga dapat disimpulkan bahwa yang paling kuat benangnya dari kedele, akan tetapi seratnya pendek, sedangkan dari bahan Kacang Merah seratnya agak panjang tetapi kurang kuat dibanding dengan kokon yang berasal dari pakan campuran kacang kedelai. 


\subsubsection{Berat Serat Kokon}

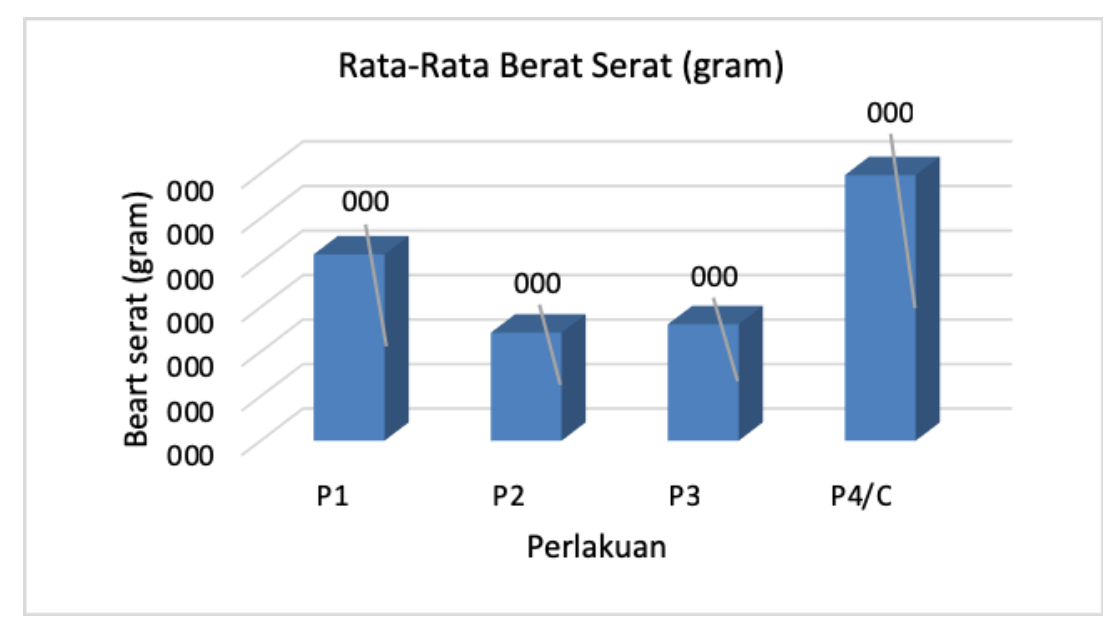

Gambar 7. Berat serat rata-rata untuk setiap Perlakuan.

Pada Gambar 7 diatas menunjukkan bahwa yang paling berat seratnya adalah pelakuan P1 dengan berat serat kokon adalah 0,21 gram, dan selanjutnya berat serat kokon P3 dan P2 masingmasing 0,13 gram dan 0,12 gram. Hal ini menunjukkan berat serat kokon kontrol masih lebih berat, tetapi diantara 3 perlakuan pakan tambahan yang mendekati kontrol adalah P1. Demikian juga dari hasil Uji Tukey pada Tabel 2 menggambarkan bahwa P1 dan P4 berbeda tidak nyata.

Hasil penelitian tentang pengaruh terhadap produktivitas kokon (berat kokon, berat kulit kokon, persentase kulit kokon, panjang serat dan berat serat) dilanjutkan dengan Uji Tukey, hasilnya dapat dilihat pada Tabel 2 berikut:

Tabel 2. Produktivitas kokon dengan pemberian pakan tambahan

\begin{tabular}{|c|c|c|c|c|c|}
\hline Perlakuan & $\begin{array}{c}\text { Berat } \\
\text { Kokon (g) }\end{array}$ & $\begin{array}{c}\text { Berat Kulit } \\
\text { Kokon (g) }\end{array}$ & $\begin{array}{c}\text { Persentase Kulit } \\
\text { Kokon (\%) }\end{array}$ & $\begin{array}{c}\text { Panjang } \\
\text { Serat }(\mathrm{m})\end{array}$ & $\begin{array}{c}\text { Berat Serat } \\
(\mathrm{g})\end{array}$ \\
\hline P1 & $0,742 \mathrm{a}$ & $0,220 \mathrm{a}$ & $29,65 \mathrm{a}$ & 685,00 & $0,209 \mathrm{a}$ \\
\hline P2 & $0,518 \mathrm{c}$ & $0,148 \mathrm{~b}$ & $28,57 \mathrm{a}$ & 490,40 & $0,121 \mathrm{~b}$ \\
\hline P3 & $0,592 \mathrm{~b}$ & $0,104 \mathrm{c}$ & $17,57 \mathrm{~b}$ & 523,80 & $0,131 \mathrm{~b}$ \\
\hline P4 & $0,714 \mathrm{a}$ & $0,212 \mathrm{a}$ & $29,69 \mathrm{a}$ & 523,80 & $0,298 \mathrm{a}$ \\
\hline
\end{tabular}


Keterangan: angka-angka pada kolom yang sama yang diikuti huruf yang sama berbeda tidak nyata pada taraf nyata $5 \%$ menurut Uji Tukey.

\subsection{Variasi Jenis Pakan Tambahan Buatan.}

Jenis pakan tambahan buatan dalam penelitian ini ada 3 variasi. Variasi yang pertama yaitu P1 (berbahan $44 \%$ Murbei, $32 \%$ Kacang Merah, $15 \%$ Agar-agar, 8\% Gula pasir dan 1\% Vitamin C), variasi ke dua adalah P2 (berbahan $44 \%$ Murbei, $16 \%$ Kacang Merah, $16 \%$ Kacang Kedelei, $15 \%$ Agar-agar, 8\% Gula pasir dan 1\%. Vitamin C), dan variasi ke tiga adalah P3 (berbahan $44 \%$ Murbei, $32 \%$ Kacang Kedelei, $15 \%$ Agar-agar, 8\% Gula pasir dan 1\% Vitamin C). Hasil penelitian menunjukkan bahwa larva yang diberi pakan $\mathrm{P} 1$, mempunyai bobot yang paling berat dan pertambahan berat yang paling tinggi (Gbr.1), serta Indeks pertumbuhan yang paling tinggi (Gbr.2), panjang larva yang paling panjang dan pertambahan panjang larva yang paling tinggi (gbr.3). Jika dilihat dari berat kokon segar (Gbr.4) dan kulit kokon paling berat, serta persentase kulit kokon paling tinggi (Gbr.5), berat serat dan panjang serat kokon tinggi (gbr.6), akan tetapi kekuatan serat nomor dua di banding dengan perlakuan lainnya. Sedangkan Pakan P2 menghasilkan bobot larva sedang (Gbr.1), indeks pertumbuhan sedang (Gbr.2), panjang larva yang paling pendek, dan pertambahan panjang larva yang paling rendah (gbr.3). Jika dilihat dari berat kokon segar (Gbr.4) juga palingrendah dan berat kulit kokon paling rendah, serta persentase kulit kokon sedang (Gbr.5), berat serat dan panjang serat kokon paling rendah (gbr.6). Sementara P3 keunggulannya di kekuatan serat yang paling tinggi. Panjang larva, berat kokon, panjang dan berat serat kokon sedang, dan paling rendah berat ulat, indeks pertumbuhan serta persentase kulit kokon. Dari hasil penelitian ini, menunjukkan bahwa variasi Jenis pakan yang paling bagus diantara jenis pakan tambahan buatan adalah P1 (berbahan 44 \% Murbei, 32 \% Kacang Merah, $15 \%$ Agar-agar, 8\% Gula pasir dan 1\% Vitamin C).

\section{KESIMPULAN}

Ada pengaruh pemberian pakan tambahan buatan terhadap ulat sutera (Bombyx mori $\mathrm{L}$ ). Hal ini berpengaruh terhadap berat larva, pertambahan berat larva, Indeks pertumbuhan, panjang larva, dan jenis pakan buatan. 
Demikian juga berpengaruh terhadap produtivitas kokon, seperti berat kokon segar, tebal tipisnya kokon (berat kulit kokon), persentase kulit kokon, berat serat, panjang serat dan kekuatan serat kokon.

Variasi pakan tambahan yang paling bagus untuk perkembangan larva adalah yang berbahan kacang merah, rata-rata berat larva per ekor, pertambahan berat larva, indeks pertumbuhan, panjang larva serta pertambahan panjang larva melebihi dari kontrol walaupun Uji Tukey menunjukkan bahwa berbeda tidak nyata dengan kontrol. Demikian juga berat kokon segar, berat serat, persentase kulit kokon, dan panjang serat, hampir menyamai kontrol. Sedangkan Pengaruh pakan buatan yang berbahan kacang kedelei lebih unggul di kekuatan serat akan tetapi panjang serat, berat ulat, indeks pertumbuhan serta persentase kulit kokon paling rendah.

\section{DAFTAR PUSTAKA}

Atmosoedarjo,et al. 2000. Sutera Alam Indonesia. Yayasan Sarana Wana jaya. Jakarta

Cahyani, K.D. 2012. Kajian Kacang Merah (Phaseolus vulgaris) sebagai Bahan Pengikat dan Pengisi pada Sosis Ikan Lele. http://digilib.uns.ac.id/pengguna.php?mn=detail\&d_id=19032. Diakses pada tanggal 8 Mei 2012.

Chowdhary, S.K. 1996. Rearing of the silkworm, Bombyx mori L.,on artificial diets: Retrospect and prospect. J. Sericologia. 36: 407-418.

Ekastuti. 2005. Pengaruh kadar air pakan terhadap pertumbuhan dan produktivitas ulat sutera Bombyx mori. Jurnal Medis Veteriner Indonesia 9(2): 47-53.

FORDA. (2016, 11 Mei). Siaran Pers: Bibit Ulat Sutera dan Murbei Unggul Untuk Memenuhi Kebutuhan Sutera Alam Nasional. Diakses pada tanggal 12 Nopember 2019 dari https://www.forda-mof.org/index.php/berita/post/2702.

Global Invasive Species Database (2011, 20 Januari). Morus alba. Diakses pada tanggal 12 Nopember 2019 dari http://www.iucngisd.org/gisd/species.php?sc=1559.

Koswara,S. 1992. Teknologi Pengolahan Kedelai. Penerbit Sinar Harapan. Jakarta.

Kumaidi A dan Ekastuti. 2013. Pertumbuhan dan Produktivitas Ulat Sutera Bombyx mori yang diberi pakan Ayam Broiler. Jurnal Acta Veterinaria Indonesia 1(1): 1-7. 
Lestari C.A. 2019. Preferensi dan Biologi Bombyx mori.L dengan Pakan Buatan Berbahan Campuran Kacang Merah (Phaseolus vulgaris). Skripsi Fakultas Kehutanan Departemen Kehutanan Universitas Hasanuddin. Makassar.

Nurhaedah, et al. 2006. Pengaruh Murbei (Morus spp.) dan Ulat Sutera Persilangan (Bombyx mory Linn.) Terhadap Kualitas Ulat, Kokon, dan Serat Sutera. Jurnal Penelitian Hutan dan Konservasi Alam Vol. III No. 1; 65-73, 2006

Ramesh, H.L., Sivaram, V. and Murthy, V.N.Y. 2014. Antioxidant and medical profeties of mulberry (Morus sp.): A review. World Journal of Pharmaceutical Research 3(6): 320-343.

Sulselprov.go.id. (2019, 29 Maret). Pemprov Sulsel Dorong Kembalikan Kejayaan Sutera Sulsel di Wajo. Diakses pada tanggal 12 Nopember 2019 dari https://Sulselprov.go.id/Welcome/post/pemprov-sulsel-dorong-kembalikan-kejayaan-suterasulsel-di-wajo.

Sunanto. 1997. Budidaya Murbei dan Usaha Persuteraan Alam. Kanisius.

Yogyakarta.

Winarsi,H. 2010. Protein Kedelai dan Kecambah Manfaat Bagi Kesehatan. Kanisius Yogyakarta. 